\title{
The application of information technology in tourism marketing mode and innovation
}

\author{
Ying MENG \\ School of Economics and Management, Wuhan University, Hubei Wuhan, 430072
}

\begin{abstract}
Key words: informatization technology; tourism industry; coordinated development; management method; marketing mode
\end{abstract}

\begin{abstract}
As a part of business, tourism also requires to keep pace with the times and the acceleration of tourism informatization can better improve the development of tourism. Information technology is a product for combination of computer software and hardware technology and modern communication technology and the application of information technology can greatly increase the efficiency of information searching, collection, sending and storage. The tourism market in China is in the transition period and the informatization development provides new opportunity for development of tourism in China. The travel agencies involve the informatization development in the revolution and development which is the demand for being geared to international standards and participating in international competition and is also the necessary means to increase the self core competitiveness. In the Thesis, the domestic tourism is the object of study and many methods are jointly applied to mainly analyze the role of informatization in tourism development according the current state of China tourism and the existing problems.
\end{abstract}

\section{Introduction}

Information technology is a product for combination of computer software and hardware technology and modern communication technology and the application of information technology can greatly increase the efficiency of information searching, collection, sending and storage. The tourism market in China is in the transition period and the informatization development provides new opportunity for development of tourism in China. The travel agencies involve the informatization development in the revolution and development which is the demand for being geared to international standards and participating in international competition and is also the necessary means to increase the self core competitiveness. As an industry directly facing consumers, tourism is an open and large system with "sightseeing, eating, sheltering and traveling" through the whole process of tourism activity, so how the demands of tourists can be met to from various aspects the greatest extent is critical for existence and development of tourism enterprises. From the perspective of consumers, with the increase of living standards and abundance of tourism experience, the demand for quality becomes increasingly evident, so the requirements for tourism industry become higher. For the tourism industry, planning and development of the scenic spot, tourism information statistics, determination of target market and formulation of market competition strategies require to be supported by the powerful informatization means, so the development of informatization development in future tourism industry is promising.

\section{Necessity of information technology for development of tourism industry}

The application of information technology has penetrated in every link of modern tourism industry and the China's access to the World Trade Organization will provide more international cooperation opportunities for domestic tourism industry; the informatization construction level of tourism industry will directly affect the future status and competition in international tourism market. He Guangwei, the Director of National Tourism Administration, emphasized for many times that: "during the process of marching from large tourism country in Asia to strong tourism country in world, the commanding height for market and technology must be actively occupied by us which is the strategic demand for development of China tourism industry" Two thirds of 
provincial and municipal domestic travel agencies in China still follow the traditional manual work at present which results in many drawbacks such as information blockade and failure to share information; single-handed struggling and scale effect not reflected; high cost and low office efficiency; failure to integrate customer information resulting in loss of customers and monitoring vulnerabilities of financial management and monitoring; lags in market response, etc. In addition, the influence of management level of domestic tourism enterprises on informatization development cannot be ignored. At present, the management softwares for domestic tourism industry are mostly rooted in the current situation of tourism enterprises, so only the computer processing for manual operation is realized, but it is impossible to cultivate the information management system with advanced management idea and standard procedures.

The person of National Tourism Administration released that: at the end of 2003, 60\% of the businesses for the national tourism management departments would be implemented through the network; the national tourism e-commerce network would be improved; try to become the important member for international tourism e-commerce; the national tourism management authorities at the level of municipality or above and $80 \%$ or more tourism enterprises could surf the Internet; establish the Level 3 domain name and webpage in the national tourism e-commerce website. Rapidly develop and open a "shortcut" for Chinese tourism to further catch up with the world advanced level. Although the tourism in China starts late, it develops rapidly and now China has become the genuine "large tourism country in Asia"; however, there is still a considerable gap with the aim of becoming "strong tourism country in the world" in 2020. Because the tourism product and the service value chain extend longer, the very strong dynamics determines that the development of tourism industry must depend on the constant innovation, share of resources and talent accumulation can fundamentally assure the corporate innovation. As the regional tourism cooperation increasingly deepens, mechanism boundary, market boundary, industry boundary, etc. hinder the development of regional tourism cooperation. Through application of information technology, establish the well-established the standard system of consultation service, build the uniform service idea, establish the uniform tourism information database and operable platform, unify the service development thought, jointly build the information database and share the resources. Under the sincere cooperation of functional departments of tourism at various levels, make full use of the public tourism information database and operable platform to effectively solve the optimal configuration of resource elements, control the problems of information operation mode and linked development, break the market separation and local protectionism with a view to truly realizing the cross-regional integration of tourism, consultation and service.

So the current tourism informatization construction will be based on the service and the business will be carried out according to the real demand of tourists; the information revolution propels the tourism-related enterprises to comprehensively increase the service efficiency and management level and promotes recreation of operation procedure in the industry; the timely, dynamic and precise management of the tourism can be realized through informatization management and information technology.

\section{Effects of information technology on tourism development}

\section{Promote innovation and progress of travel agency}

As the middle service provider, the main functions of travel agency include providing consultation service, ticket business, design and promotion of tourism products. But with the popularity of information technology, the agency is greatly impacted; in case it does not rebuild the living cornerstone, it may disappear. With the development and popularity of network technology and the enrichment of network resources, tourists can search the required information about tourism destination, surrounding hotels and other information at home. Therefore, the consultation service provided by the agency is in the risk of being replaced by the network information search. Ticket agency is also another important service provided by the travel agency, but until now, all the 
airlines own their own booking websites, the train ticket can also be bought through 12306 which necessarily impact the ticket agency service of the travel agency. With the deepening of informatization, the travel agency must put forward the corresponding countermeasures for the confronted problems, constantly innovate and keep pace with the times to make its development remain invincible.

\section{Be favorable to publicity and marketing of tourism product}

Most of the traditional tourism products are publicized through advertising media such as newspaper, magazines and TV advertisement with poor effect. But the progress of information technology can bring many benefits for publicity and marketing of tourism product. In publicity, the information technology can use sound, light and electricity to demonstrate the tourism product to the tourists from multi-dimensional perspective which makes the tourism products more sufficiently demonstrated and more attractive. In addition, tourists can communicate their experience of tourism product to others through network to promote the improvement of poor tourism product and make the well-reputed tourism product perfect. In marketing of tourism product, another marketing mode is provided to the tourism enterprises by network and the sales mode of tourism product turns from off-line selling to the combination mode of online selling and offline selling which is favorable to sales and promotion of the tourism products.

\section{Promote development of tourism e-commerce}

In 2010, the market size of China tourism e-commerce (based on online tourism transaction of Internet platform) reached 200 billion yuan accounting for nearly 15\% of the total tourism income. Promoted by continuous expansion of tourism market and wide application of information technology, the different types and modes of tourism e-commerce entities develop rapidly. From the current trend, the tourism e-commerce shows sign of monopoly competition in local filed, but in general, the market does not step into the mature stage of hierarchical competition and classified competition and shows more penetration into the market share of traditional tourism market [2]. We are now in an information era and as time goes on, the network will become more and more mature and important. The rapid development of e-commerce is a good example. Li Keqiang, the Premier, repeatedly mentioned the word "Internet+" in National People's Congress and the Chinese Political Consultative Conference this year. So it can be seen that informatization is a trend. At present, with the rapid development and popularity of Internet in the world, the results of information technology gradually penetrate in various aspects in people's social life and production; as a new means of exchange and commence mode, e-commerce enters into various fields of traditional commerce including tourism at an unprecedented speed. The tourism e-commerce is of unlimited potential and it will become the new mode for future tourism marketing. After several years of exploring and accumulation, there are many tourism websites with certain information service ability in the country and the websites can provide relatively comprehensive online information services including eating, sheltering, traveling, sightseeing, purchasing, entertainment, etc. in the trip. Only through informatization road and being geared to the international tourism development can the tourism in China open a new way and make contribution to development of national economy.

\section{Conclusion}

Information technology has deeply penetrated in various fields of social life. In early time of the last century, the Internet technology which is the new representative of information technology exerted unprecedented influence on development of tourism after it is introduced in the tourism industry. Besides improving Information management for tourism enterprises, it promotes the electronic transaction of tourism product much more. The "Golden Tourism Project" built at the beginning of the year in China aims to promote the application of information technology in tourism development, improve the business management of tourism enterprises and further promote 
the benign development of tourism. The information technology affects tourism in an all-round way which necessarily results in the coming of informatization tourism time.

\section{Reference}

[1] Katsoni V, Venetsanopoulou M. Use of innovation systems for an effective tourism marketing development strategy.[J]. e-Journal of Science \& Technology, 2013.

[2] Weiermair K, Peters M, Pikkemaat B. Prospects for innovation in tourism: analyzing the innovation potential throughout the tourism value chain.[J]. Journal of Quality Assurance in Hospitality \& Tourism, 2005, 6(3):59-72.

[3] Katsoni V. The strategic role of virtual communities and social network sites on tourism destination marketing.[J]. e-Journal of Science \& Technology, 2014, vol.9:107-117.

[4] Baggio R. Technological Innovation in e-Tourism: The Role of Interoperability and Standards[M]// Tourism Management, Marketing, and Development. Palgrave Macmillan US, 2014.

[5] Brea J A F, Brea J A F. The constant evolution of tourism: innovation, technology, new products and experiences.[J]. Pasos Revista De Turismo Y Patrimonio Cultural, 2015. 